\title{
FAMILY SUPPORT AND IMPLEMENTATION TECHNOLOGY FOR MENTAL RETARDATION STUDENT
}

\author{
Susanto \\ Universitas Negeri Surabaya \\ Email : susantosanto36@yahoo.com
}

\begin{abstract}
Every family wants all members of the family can grow and develop normally, especially children, but sometimes can not be obtained by families who have a child born with retardation mental. They feel that children with disabilities / mental retardation is a family disgrace, it is because of ignorance of families with children with mental retardation and problems the lack of information obtained.

Some $15 \%$ of the Inhabiting number of the world, or approximately the as many as one billion people, is people with disability. Based on random survey conducted by the ministry of social affairs of Indonesia in 1978 the population of disabled people is 3,11 $\%$ of the population in Indonesia. While the who data in 2004 estimated that the population of disabled people 10 percent of the total population of Indonesia. Data collection about the total number of voters and the population data collection about the total number of voters of disabled people in 2004 general election which conveyed by the central bureau of Statistics Government, based on survey 309.146 as many as a blind person around, 192. 207 deaf, 178.870 mentally retardation 94.423 defect and other. The data are still need the data collection system that carefull, it impeded because of factors; ignorance family and community to the issue of disability, culture of family, the stigma of the community, isolation from family, over protected, discrimination, low priority support

This study aimed to get an overview of family support in the care of mentally retarded children at SLB (Special Need Education) Padangsidimpuan, Indonesia. This study used a descriptive design, samples were taken with total sampling method ( group samples are 100 family with mentally retardation and 49 children with mental retardation) and instruments used in the form of a questionnaire. Data processed by the system computerization in the frequency distribution table and percentages.

Data collection was conducted on 12 July until 30 July 2011. Test reliability This research at 0.7245 by using $\mathrm{kr} 21$. From research obtained good results family support as many (74\%), which consists of support information (72\%), support of assessment (81\%), instrumental support (67\%), and emotional support (74\%). Family support is very important in caring for retarded children, and to increase the sense of self confidence retarded child mental. The results of this study are expected to assist nurses in providing information on family support in caring for children mental retardation.
\end{abstract}

Keywords: Family Support, Mental Retardation, Tecnology.

\section{INTRODUCTION}

According to Doherty \& champbell (1998) in Newton (2006) that the family has a major impact on the physical and mental health of every member of the family. So the role of the family is specific behavior expected by a person in the family context that describes a set of interpersonal behavior, nature, activities related individuals in positions and situations according Setiadi (2008) in 
research Rizqika (2009). Every family wants all members of the family can grow and develop normally, especially children. But this sometimes can not be obtained by the family, especially parents whose children are born with some abnormality, one of which is mental retardation.

According AAMD (The American Association For Mental Deficiency) mental retardation is a condition where the general intelengensi functioning under the average - average, which began during the developmental period and accompanied by disturbances in behavior adjustments. Mental retardation is not a disease although mental retardation is the result of pathological processes in the brain and provide a description of the limitations of the intellectual and adaptive functioning.

Mental retardation can occur with or without a psychiatric disorder or other physical disorders (Judarwonto, 2009). Mental retardation is a characteristic associated with Down syndrome, and this situation is somewhat less enjoyable because of mental retardation in such a group of severe mental retardation to the medium. Rarely them with such a state can reach IQ up to 50. The diagnosis is often easier to create in children a larger, yet more difficult in infants - babies are still small.

.Based on data from the Center for Data and Information (Media Centre) Social Welfare Ministry of Social Affairs in 2006 the number of people with disabilities is 2.364 million people including mental disabilities, while the random survey. Ministry of Social Affairs in 1978 is $3.11 \%$ of the total Indonesian population estimated in 2002 at 212020 759, the amount of 6,593,846 people with disabilities, including mental disabilities amounted to 848083 people. According Susenas 2003 the number of disabled people with mental retardation is 237590 inhabitants, and the ex-psychotic mental 150519 people. the number of mentally disabled people with disabilities is $3 \%$ of Indonesia's population, amounting to 6 million people (Cloud, 2008)

People who most suffer from mental retardation are the parents and the child's family. When the crisis is when the family was first realized that their children do not normally like any other child. The reaction of parents vary depending on various factors, such as whether the disability can be readily known or learned too late. Another very important factor is the degree of backwardness and the clear absence of defects visible to others (Somantri, 2006).

Surve beginning that researchers do in School (SLB) Padangsidimpuan, found as many as 49 children of various ages. Based on evaluation of data SLB Padangsidimpun, the number of students who have mental retardation were a total of 11 people and light as many as 38 people.

Based on the above description that kelurga played an important role in caring for sick family members in this case and in the development of mental retardation can be achieved by a child. Therefore, researchers interested in conducting research on family support in caring for mentally retarded children in SLB Padangsidimpuan. Sumatra 


\section{Problem}

"How to describe of family support in caring for mentally retarded children in SLB Padangsidimpuan? "

\section{The purpose of this study was:}

1. Identify family support in caring for mentally retarded children in SLB Padangsidimpuan.

2. Identify infomasional support in caring for mentally retarded children in SLB Padangsidimpuan.

3. Identify support on votes in the care of mentally retarded children at SLB Padangsidimpuan

4. Identify the instrumental support in caring for mentally retarded children in SLB Padangsidimpuan

5. Identify the emotional support in caring for mentally retarded children in SLB Padangsidimpuan.

\section{Design/Procedure}

This study used a descriptive design, samples were taken with total sampling methods and instruments used questionnaire data was processed by a computerized system in the form of a frequency distribution table and the percentage of data collection was done on 12 July until 30 July 2011 Test reliability of the study amounted to 0.7245 by using $\mathrm{kr} 21$

\section{Finding Analysis/research results}

From the research results support good family that is as much (74\%), which consists of information support (72\%), support of assessment (81\%), instrumental support (67\%), and emotional support (74\%) Family support is very important in caring for retarded children, and to increase the confidence of mental retardation research results are expected to assist nurses in providing information on family support in caring for mentally retarded children

\section{CONCLUSION}

Based on the analysis and discussion, it can be concluded and advice on family support in caring for mentally retarded children in SLB field Sidimpuan Conclusion Based on the results of research on 43 respondents in SLB Padangsidimpuan known that most respondents have family support in caring for mentally retarded children in both categories as ( $74 \%)$, sufficient for $(25 \%)$ of respondents support the family in caring for mentally retarded children covering several aspects: Support information - Category well: $71 \%$ of respondents - Category enough: $26 \%$ of respondents Category less: $2 \%$ of respondents support ratings - Category well: $81 \%$ of respondents - Category 
enough: $12 \%$ of respondents - Category lacking:\% of respondents 49 North Sumatra University cd Support instrumental - Category well: $67 \%$ of respondents - Category enough: $28 \%$ of respondents Category less: 5\% of respondents emotional support - Category well: $74 \%$ of respondents Category enough: $23 \%$ of respondents - less Category: $2 \%$ of respondents.

From the results obtained, the researchers concluded that family support in caring for mentally retarded children in SLB Padangsidimpuan have had good support in caring for children with mental retardation

\section{Recommendation}

1. The Children with mental retardation must be supported by family

2. The Family must give supported by teacher to care children with mental retardation

3. The Institution mus give motivation for the family of mental retardation children

\section{BIBLIOGRAPHY}

Newton, DA (2006) Effect of Families Against Health Taken from website: http://www.Scribd.com (downloaded on 11 March 2011) Nichcy (1997) Mental Retardation Taken from the website: http: //www.nichcy,com ( downloaded on 11 March 2011)

Nursalam (2003) Concept and Determination of Nursing Jakarta: Salemba

Medika Nursalam Science Research Methodology (2004) Concept and Determination of Nursing Jakarta: Salemba Medika

Science Research Methodology Perry \& Potter (2005) Textbook of Fundamental nursing Jakarta: EGC Riyadi,

Sujono 2009 Nursing in children Yogyakarta Graha Science Rizqina, Maramah (2009) 